\title{
Stratifikasi Sosial Dalam Novel Negeri Di Ujung Tanduk Karya Tere Liye
}

\author{
Venita Utari ${ }^{1}$, Mardian ${ }^{2}$, Gunta Wirawan ${ }^{3}$ \\ STKIP Singkawang, Singkawang, Indonesia

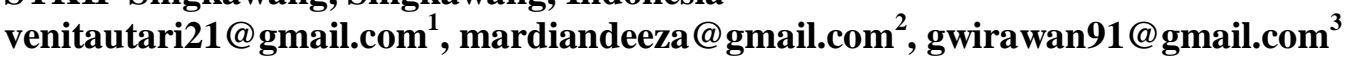

Keywords :

Kekuasaan, Sosiologi Sastra

\section{ABSTRACT}

Sosial, Tujuan penelitian ini adalah untuk mengetahui stratifikasi sosial yang terdapat dalam novel Negeri di Ujung Tanduk Karya Tere Liye.Tujuan khusus penelitian ini adalah untuk mendapatkan informasi sebagai berikut: (1) pendeskripsian kelas sosial dalam novel Negeri di Ujung Tanduk Karya Tere Liye; (2) pendeskripsian status sosial dalam novel Negeri di Ujung Tanduk Karya Tere Liye; (3) pendeskripsian kekuasaan dalam novel Negeri di Ujung Tanduk Karya Tere Liye;dan(4) pendeskripsian implementasi rencana pembelajaran di sekolah.Metode penelitian ini adalah metode deskriptif dengan bentuk kualitatif.Penelitian ini menggunakan pendekatan sosiologi sastra.Sumber data penelitian ini yaitu novel Negeri di Ujung Tanduk Karya Tere Liye.Data dalam penelitian ini yaitu berupa kata, frasa, dan kalimat.Teknik analisis data meliputi pengklasifikasian, penginterpretasian, dan penyimpulan.Berdasarkan hasil analisis dari Negeri di Ujung Tanduk maka dapat disimpulkan: (1)kelas sosial terdapat 11 kutipan yang terdiri dari pendidikan, ekonomi;(2) Status Sosial terdapat 12 kutipan yang terdiri dari status bawaan, simbol status, peran; (3) kekuasaan terdapat 10 kutipan yang berhubungan dengan bidang politik; (4) implementasi rencana pembelajaran di sekolah dapat diterapkan pada sekolah SMA kelas XII semester 1, pengajaran tentang novel yang meliputi standar kompetensi mendengarkan: 5. Memahami bentuk penggalan novel dengan kompetensi dasar 5.1 menjelaskan unsur intrinsik penggalan novel dengan menggunakan metode Jigsaw.

\section{INTRODUCTION}

Novel adalah karya sastra yang lebih panjang dari cerpen dan menceritakan kehidupan seseorang lebih mendalam dengan menggunakan bahasa sehari-hari banyak membahas tentang aspek kehidupan manusia. Sebuah novel terdapat unsur yang dapat diteliti agar dapat menggambarkan makna dan nilai yang terkandung di dalamnya, yakni unsur intrinsik dan unsur ekstrinsik.

Peneliti memilih novel Negeri di Ujung Tanduk karena novel Negeri di Ujung Tanduk mempunyai masalah sosial yang menarik untuk dikaji. Dilihat dari segi ceritanya Thomas yang menjadi tokoh utama dalam novel tersebut yang menceritakan tentang adanya perlawanan memberantas kejahatan 
kehidupan politik seperti korupsi, karena kurangnya kepedulian dan kesadaran dari masyarakat untuk membela suatu kehormatan dan kebenaran dalam kehidupan. Di mana para penipu menjadi pemimpin, para pengkhianat menjadi pujaan karena ketidakpedulian terhadap kehidupan yang mereka jalani sehingga timbullah kesenjangan sosial antar masyarakat. Dalam hal ini tugas sosiologi sastra adalah menghubungkan keadaan seseorang di dalam sebuah cerita dengan kehidupan nyata atau kehidupan sehari-hari. Hubungan antara sosiologi sastra dengan stratifikasi sosial adalah mengemukakan sistem kemasyarakatan dalam sebuah penelitian yang dapat dilihat dari kelas-kelas sosial maupun status sosial yang dilatarbelakangi adanya nilai-nilai yang dihargai dalam masyarakat dan sistem pelapisan sosial.

Stratifikasi sosial adalah pembedaan penduduk atau masyarakat ke dalam kelas-kelas secara bertingkat-tingkat atau hierarkis (Soerjono 2013: 198). Sistem berlapis-lapis hanyalah suatu konsep realitas sosial yang menjelaskn adanya pelapisan sosial karena dilatarbelakangi oleh adanya nilai yang dihargai dalam masyarakat dan sistem pelapisan sosial ini merupakan realitas sosial. Peneliti tertarik untuk menganalisis tentang stratifikasi sosial karena manusia merupakan unsur pembentuk masyarakat. Biasanya kehidupan di masyarakat, manusia atau anggota masyarakat ingin selalu dihargai dan dihormati. Pasti hal tersebut akan menjadi bibit yang dapat menumbuhkan adanya sistem lapisan dalam masyarakat. Sesuatu yang dihargai dalam masyarakat dapat bernilai ekonomis, kekuasaan, ilmu pengetahuan, kesalehan, pangkat, dan keturunan yang terhormat yang mengakibatkan terjadinya stratifikasi sosial. Perwujudannya adalah kelas-kelas tinggi dan kelas yang lebih rendah, dan lapisan masyarakat tidak adanya keseimbangan dalam pembagian hak dan kewajiban-kewajiban tanggung jawab nilai-nilai sosial dan pengaruhnya diantara anggota-anggota masyarakat. Sebab pada dasarnya hak dan kewajiban setiap manusia itu sama dalam segala hal. Hal inilah yang menyebabkan peneliti tertarik untuk meneliti tentang stratifikasi sosial, peneliti ingin mengetahui lebih dalam apa penyebab yang melatarbelakangi hingga adanya lapisan-lapisan dalam masyarakat.

Dalam kaitannya dengan pembelajaran Bahasa Indonesia maka hubungan penelitian ini terdapat dalam (KTSP) Kurikulum Tingkat Satuan Pendidikan pada SMA kelas sebelas (XII) Semester 1 Standar Kompetensi (SK) Mendengarkan : 5. Memahami pembacaan novel. Kompetensi Dasar (KD) 5.2 Menjelaskan unsur intrinsik dari pembacaan penggalan novel. Indikator dalam pembelajaran yaitu menjelaskan unsur-unsur intrinsik dalam penggalan novel.

\section{METHOD}

Metode yang digunakan dalam penelitian ini adalah metode deskriptif. Moleong (2013: 11) mengungkapkan bahwa metode deskriptif merupakan metode data yang dikumpulkan adalah berupa kata-kata, gambar, dan bukan angkaPenulis menggunakan metode ini untuk menggambarkan stratifikasi sosial dalam novel Negeri di Ujung Tanduk meliputi kelas sosial, status sosial, dan kekuasaan serta implementasi terhadap rencana pembelajaran di sekolah.

Bentuk penelitian yang digunakan dalam penelitian ini adalah kualitatif. Menurut Moleong (2013: 9) penelitian kualitatif yaitu penelitian yang menggunakan pengamatan, wawancara, ataupun menelaah dokumen. Pendekatan yang digunakan dalam penelitian adalah pendekatan sosiologi sastra. Menurut Endaswara (2013: 77) sosiologi sastra adalah cabang penelitian sastra yang bersifat reflektif. Dalam penelitian ini pendekatan sosiologi sastra berarti menganalisis tentang kehidupan bermasyarakat yang dapat dilihat dari permasalahan sosial khususnya status sosial, kelas sosial dan kekuasaan yang terdapat dalam novel Negeri di Ujung Tanduk.

\section{RESULTS AND DISCUSSIONS}

Dalam penelitian ini pendekatan sosiologi sastra berarti menganalisis tentang kehidupan bermasyarakat yang dapat dilihat dari permasalahan sosial khususnya status sosial, kelas sosial dan kekuasaan yang terdapat dalam novel Negeri di Ujung Tanduk. 


\section{Kelas Sosial}

Kelas sosial adalah semua orang dan keluarga yang sadar akan kedudukannya di dalam suatu lapisan, sedangkan kedudukan mereka itu diketahui serta diakui oleh masyarakat umum. Kelas sosial dapat didefinisikan sebagai suatu strata atau lapisan orang-orang yang berkedudukan sama dalam rangkaian kesatuan status sosial. Hal ini dapat diperjelas dalam kutipan berikut.

"check! Kita juga punya kepala pemerintahan yang hidup serumah dengan wanita di luar ikatan pernikahan, bangga menunjukkannya ke rakyatnya, mempertontonkan sesuatu yang boleh jadi merupakan skandal besar di negara lain, tapi atas nama demokrasi, dia justru memenangi pemilu di negaranya, dan wanita pasangan di luar nikahnya menjadi ibu negara, wanita paling terhormat di negeri tersebut. (Liye, 2013:21)

Masalah yang didapat dalam kutipan tersebut menggambarkan adanya kelas sosial tentang suatu kekayaan seseorang dan jabatan yang tinggi. Sehingga dengan jabatan yang tinggi tersebut maka seseorang tersebut menjadi terpandang dan terhormat dikalangan masyarakat bawah.

\section{Kedudukan/Status Sosial}

Status sosial adalah suatu kedudukan sosial seseorang di masyarakat yang dapat diperoleh dengan sendirinya melalui usaha ataupun kerena pemberian. Status sosial terdapat pada kutipan berikut.

"Aku tertawa kecil, menepuk lengan James, akademisi salah satu sekolah politik terkenal di Asia Pasifik, yang bertindak menjadi moderator siang itu.” Ruangan besar itu dipenuhi galak tawa peserta konferensi."(Liye,2013: 30)

Masalah yang terdapat pada kutipan di atas menjelaskan tentang seseorang yang mempunyai kedudukan yang tinggi terpandang serta terhormat di dalam masyarakat. Sehingga seseorang tersebut menjadi terkenal serta disegani oleh masyarakat bawah. Dalam kutipan tersebut terdapat kedudukan sosial dalam lingkungan kerja, seseorang yang mempunyai kedudukan tinggi lebih terhormat mendapat pandangan yang bagus dibandingkan dengan seseorang yang memiliki kedudukan rendah.

\section{Kekuasaan}

Sosiologi mengakui kekuasaan sebagai unsur yang sangat penting dalam kehidupan suatu masyarakat. Adanya kekuasaan cenderung tergantung dari hubungan antara pihak yang memiliki kemampuan untuk melancarkan pengaruh dengan pihak lain yang menerima pengaruh itu. Berdasarkan penjelasan di atas kekuasaan terdapat pada kutipan di bawah ini.

"Hadirin!” aku mengangkat tangan, memasang intonasi suara serius dan bertenaga," Maafkan saya, tapi saya akan tegaskan di depan kalian semua,”(Liye,2013: 20)

Berdasarkan kutipan di atas menggambarkan adanya seseorang yang menegaskan dan mempengaruhi tentang politik kepada masyarakat lain. Pada dasarnya seseorang yang mempunyai kekuasaan senantiasa memberi pengaruh dan perintah kepada kelompok lain atau bawahannya agar orang lain turut melakukan sesuai dengan keinginannya. Kutipan tersebut menjelaskan bahwa seseorang yang mempengaruhi kepada orang lain tentang politik, sehingga orang lain tersebut menjadi mudah percaya dengan apa yang di bicarakan oleh seseorang tersebut.

\section{Implementasi Rencana Pembelajaran Dalam Novel Negeri di Ujung Tanduk Karya Tere Liye Terhadap Pembelajaran Bahasa Di Sekolah}

\section{a. Ditinjau dari Aspek Kurikulum}

Penelitian tentang stratifikasi sosial dengan pembelajaran sastra Indonesia terdapat dalam Kurikulum Tingkat Satuan Pendidikan (KTSP) pada SMA kelas (XII) semester 1 dengan Standar Kompetensi (SK) Mendengarkan: 5. Memahami pembacaan novel. Kompetensi Dasar (KD) 5.2 Menjelaskan unsur intrinsik dari pembacaan penggalan novel. Indikator dalam pembelajaran yaitu menjelaskan unsur intrinsik dalam penggalan novel. Standar kompetensi pembelajaran Bahasa Indonesia dalam KTSP mencakup dengan empat kompetensi berbahasa yaitu kompetensi berbahasa menyimak, membaca, berbicara, dan menulis. Standar kompetensi di atas termasuk juga di dalam kompetensi kesastraan, semuanya terkait dengan kompetensi berbahasa dan tidak ada secara khusus menunjuk atau terlepas darinya. 


\section{b. Ditinjau dari Aspek Tujuan Pembelajaran Sastra}

Dalam pembahasan kali ini, peneliti akan membahas secara khusus tujuan pembelajaran sastra yang terlihat dalam standar kompetensi dan kompetensi dasar (KTSP) mata pelajaran Bahasa Indonesia yang ada di kelas XII semester 1 di tingkat SMA. Dengan standar kompetensi mendengarkan 5. Memahami pembacaan novel. Kompetensi dasar 5.2. Menjelaskan unsur intrinsik dari pembacaan penggalan novel. Indikator dalam pembelajaran tersebut yaitu menjelaskan unsur intrinsik dalam penggalan novel. Dalam hal ini dapat ditarik kesimpulan bahwa tujuan pembelajaran sastra yang sesuai dengan standar kompetensi dasar di atas adalah pertama, siswa dapat memahami unsur-unsur dalam novel Indonesia/terjemahan. Kedua, siswa dapat mengidentifikasi unsur-unsur intrinsik dalam novel Indonesia/terjemahan. Ketiga, yaitu siswa dapat menganalisis unsur-unsur intrinsik (alur, tema, penokohan, sudut pandang, latar, dan amanat) novel Indonesia.

\section{c. Ditinjau dari Aspek Metode Pembelajaran Sastra}

Dalam pembahasan kali ini, sesuai dengan peran guru, peran siswa, materi, tahap evaluasi pembelajaran sastra, dan tujuan pembelajaran sastra yang terdapat dalam standar kompetensi dan kompetensi dasar (KTSP) mata pelajaran Bahasa Indonesia kelas XII semester 1 tingkat SMA. Dengan standar kompetensi Mendengarkan 5. Memahami pembacaan novel. Kompetensi dasar 5.2. menjelaskan unsur intrinsik dari pembacaan penggalan novel. Dengan ini peneliti dapat menggunakan metode Jigsaw dalam pembelajaran.

Metode pemebelajaran sastra dengan tipe Jigsaw ini, peneliti dapat merasakan bahwa adanya menggunakan metode tersebut, pembelajaran dengan standar kompetensi dan kompetensi dasar dapat menolong peserta didik lebih aktif dan saling membantu dalam menguasai materi pelajaran untuk mencapai prestasi yang maksimal. Pembelajaran Jigsaw ini merupakan model pembelajaran dengan cara membagi kelompok kecil untuk dapat mengerjakan soal-soal yang nantinya diberikan oleh guru kepada siswa, agar siswa tersebut dapat bekerja sama dengan baik dalam memecahkan soal yang telah diberikan. Dalam pembelajaran Jigsaw ini peneliti dapat mengemukakan bahwa aktivitas atau langkah-langkah dari Jigsaw meliputi hal sebagai berikut.

a. Guru membagi topik pelajaran menjadi empat bagian/subtopik. Misalnya topik tentang novel dibagi menjadi alur, tokoh, latar, dan tema.

b. Sebelum subtopik diberikan, guru memberikan pengenalan mengenai topik yang akan di bahas. Guru bisa menuliskan topik di papan tulis dan bertanya kepada siswa apa yang mereka ketahui mengenai topik tersebut.

c. Siswa dibagi menjadi beberapa kelompok

d. Siswa diminta membaca dan mengerjakan bagian subtopik yang telah dibagi guru kepada masing-masing kelompoknya.

e. Khususnya untuk kegiatan membaca guru dapat membagi bagian-bagian sebuah cerita yang belum utuh kapada masing-masing siswa. Siswa membaca bagian tersebut untuk memprediksi apa yang dikisahkan dalam cerita tersebut.

f. Kegiatan bisa diakhiri dengan diskusi mengenai topik tersebut. Diskusi bisa dilakukan antarkelompok atau sesama seluruh siswa.

Peneliti mengharapkan di dalam pelaksanaannya dan penerapannya dapat bermanfaat bagi peserta didik dan guru Bahasa dan Sastra Indonesia. Manfaat yang dapat diambil dan dirasakan adalah peserta didik dapat bekerja sama dengan peserta didik lainnya dalam memecahkan soal yang diberikan oleh guru dan mengajarkan adanya tanggung jawab pada peserta didik.

\section{d. Ditinjau dari Aspek Media Pembelajaran Sastra}

Peneliti menggunakan media cetak di dalam pembelajaran sastra karena, media cetak sesuai dengan kompetensi dasar dan bahan ajar yang akan peneliti bahas yaitu kompetensi dasar 5.2. menjelaskan unsur intrinsik dari pembacaan penggalan novel. Dengan menggunakan media cetak, sesuai dengan kompetensi di atas, peneliti atau guru Bahasa Sastra dan Indonesia dapat menghantarkan pesan atau informasi kepada peserta didik, dan dapat memberikan gambaran awal untuk mencari dan menemukan sebuah pemahaman yang saling berkaitan antara film, novel, maupun karya sastra lainnya. Dalam hal 
ini dapat dikatakan bahwa proses pembelajaran bisa lebih menarik dan menyenangkan bagi peserta didik, sehingga peserta didik seolah-olah tidak merasa sedang belajar.

\section{CONCLUSION AND SUGGESTION}

Berdasarkan analisis data dengan pendekatan sosiologi sastra yang dilakukan terhadap novel Negeri di Ujung Tanduk maka peneliti dapat menarik kesimpulan mengenai Stratifikasi Sosial dalam novel Negeri di Ujung Tanduk adalah Kelas sosial berhubungan dengan kedudukannya di dalam suatu lapisan, sedangkan kedudukan mereka itu diketahui serta diakui oleh masyarakat umum. Dari penelitian ini, peneliti menemukan 11 kutipan. Status sosial meliputi suatu kedudukan sosial seseorang di masyarakat yang dapat diperoleh dengan sendirinya melalui usaha ataupun kerena pemberian. Dari penelitian ini, peneliti menemukan 11 kutipan. Kekuasaan dapat diartikan sebagai kemampuan untuk memengaruhi pihak lain menurut kehendak yang ada pada pemegang kekuasaan tersebut. Dari penelitian ini, peneliti menemukan 10 kutipan yang berhubungan dengan kekuasaan. Berdasarkan kurikulum (KTSP) terdapat empat aspek keterampilan berbahasa yang sangat penting, yaitu keterampilan menyimak, berbicara, membaca, dan menulis. Adapun yang akan dibahas dalam penelitian ini yaitu keterampilan mendengarkan. Pada kelas /semester: XII/1 dengan standar kompetensi mendengarkan 5.Memahami pembacaan novel. Kompetensi dasar 5.2.menjelaskan unsur intrinsik dari penggalan novel Indikator dalam pembelajaran yaitu menjelaskan unsur intrinsik dalam penggalan novel, dengan menggunakan metode Jigsaw dalam pembelajaran Bahasa di Sekolah. Saran yang dapat disampaikan peneliti berdasarkan hasil penelitian ini adalah Kepada pembaca diharapkan memahami makna tentang kelas sosial yang terkandung sehingga dapat memanfaatkan kelas sosial yang terdapat dalam karya sastra khususnya pada novel Negri di Ujung Tanduk karya Tere Liye. Dalam menyikapi permasalahan yang dihadapi dan dapat dijadikan pedoman dalam menentukan pergaulan di kehidupan masyarakat. Bagi pengajar khususnya pengajar Bahasa dan Sastra Indonesia dapat menjadikan kelas sosial kepada peserta didik sehingga peserta didik dapat menjadi lebih baik lagi dalam bermasyarakat. Selanjutnya dalam proses pembelajaran, pengajar harus dapat menciptakan suasana yang berinovatif yaitu dengan memilih metode dan media yang tepat dan menarik untuk menumbuhkan minat peserta didik dalam pembelajaran sastra.

\section{REFERENCES}

Endraswara.2013. Metodologi Penelitian Sastra. Yogyakarta: FBS Universitas Negeri Yogyakarta.

Liye,Tere. 2015. Negeri Di Ujung Tanduk. Jakarta: PT Gramedia Pustaka Utama.

Moleong, Lexy J. 2013. Metodologi Penelitian Kualitatif. Bandung: PT. Remaja Rosdakarya.

Soekanto Soerjono. 2013. Sosiologi Suatu Pengantar. Jakarta: PT. Rajagrafindo Persada. 